\title{
Basal cell carcinoma presenting as symptomatic iron deficiency anaemia
}

\author{
Michael D Breglia, ${ }^{1}$ Patricia Oliva²
}

${ }^{1}$ Department of Internal Medicine, University of South Florida, Tampa, Florida, USA;

2University of Florida, Tampa, Florida, USA

Corresponding to Michael D Breglia,mbreglia@health.usf.edu

\section{DESCRIPTION}

A 58-year-old white gentleman presented to an outpatient clinic with a 6-month history of fatigue and dyspnoea on exertion. The patient worked as a block mason and reported that he became short of breath when slowly walking over 100 yards. For at least 10 years, he had a medical history of hypertension and chronic low back pain. As a child he received head irradiation for an unknown fungal infection. At his outpatient visit, the patient was found to be severely anaemic and was referred for hospital admission.

Upon admission, the patient was also noted to have several large erythematous weeping and ulcerated lesions on his scalp, posterior neck and also the pinna of his left ear. Most notable was a $12 \times 9 \mathrm{~cm}$ lesion covering the vertex of the scalp (figures 1 and 2). The patient confirmed that these ulcerations began as a coin-sized lesion that had unroofed and progressively expanded over the course of about 8 years. He regularly wore a baseball cap to conceal the unsightly wound. According to the patient, the scalp lesion had been bleeding intermittently and actively draining for the past several years.

At presentation, the patient was afebrile. His pulse was 106. He was without laboured breathing or tachypnoea. Mucous membranes were moist. Other than his striking cutaneous findings, the remainder of his physical examination was otherwise unremarkable. Laboratory studies confirmed a severe anaemia. He was found to have a haemoglobin $5.8 \mathrm{~g} / \mathrm{dl}$ (reference range: $14-17 \mathrm{~g} / \mathrm{dl}$ ) with a mean corpuscular volume of $65.5 \mathrm{fl}$ (reference range: 80-100 fl). Peripheral smear showed profoundly hypochromic, microcytic red blood cells. The absolute reticulocyte count was inappropriately low at $71.1 \mathrm{~g} / 1$ (reference range: 24-101) given his degree of anaemia. Ferritin was significantly decreased at $5 \mathrm{ng} / \mathrm{ml}$ (reference range: 32-284). Fecal occult blood testing was negative on three separate specimens. He was subsequently given three units of packed red blood

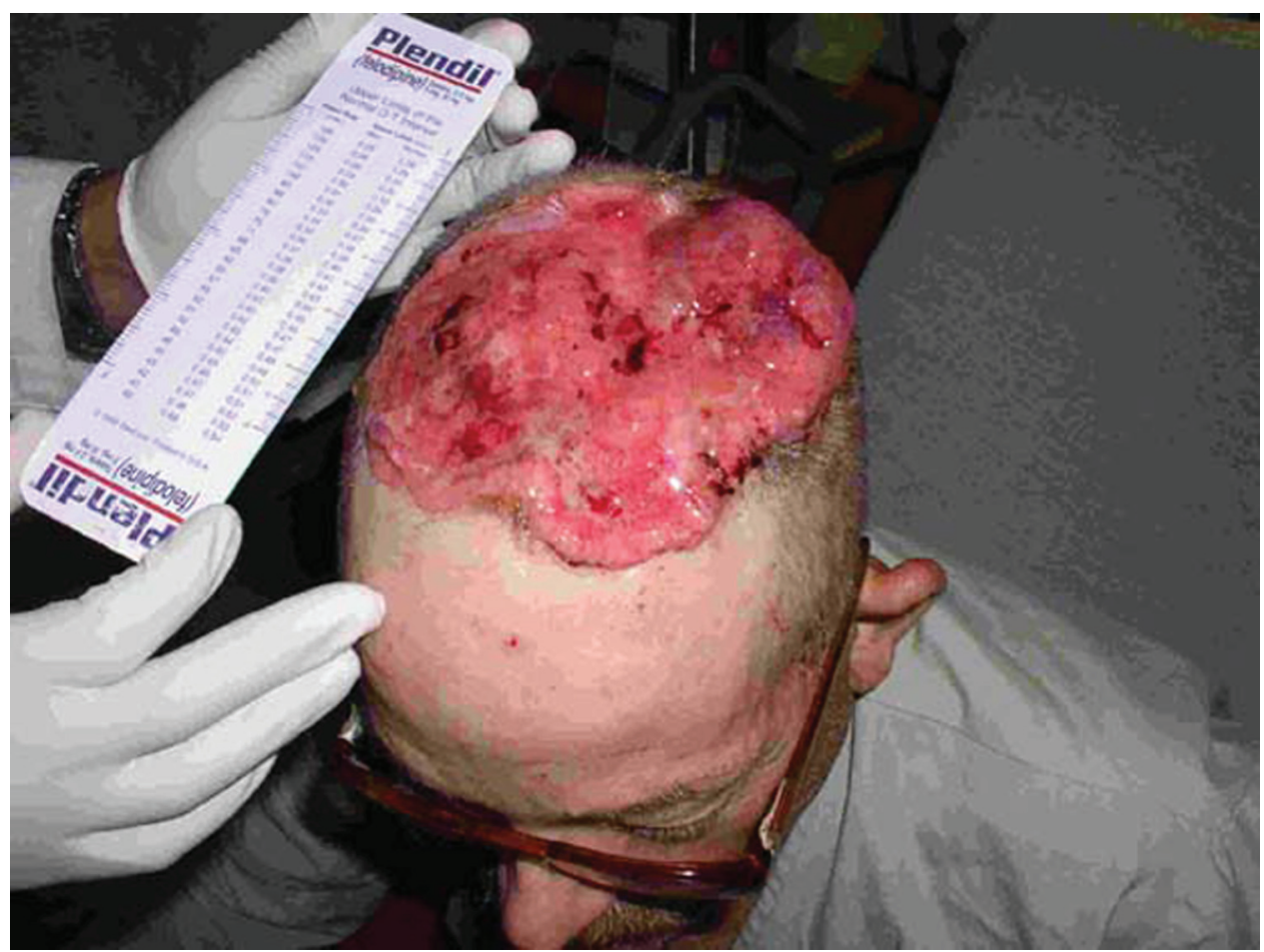

Figure 1 Locally invasive BCC which began as a coin-sized lesion 8 years ago. 


\section{BMJ Case Reports}

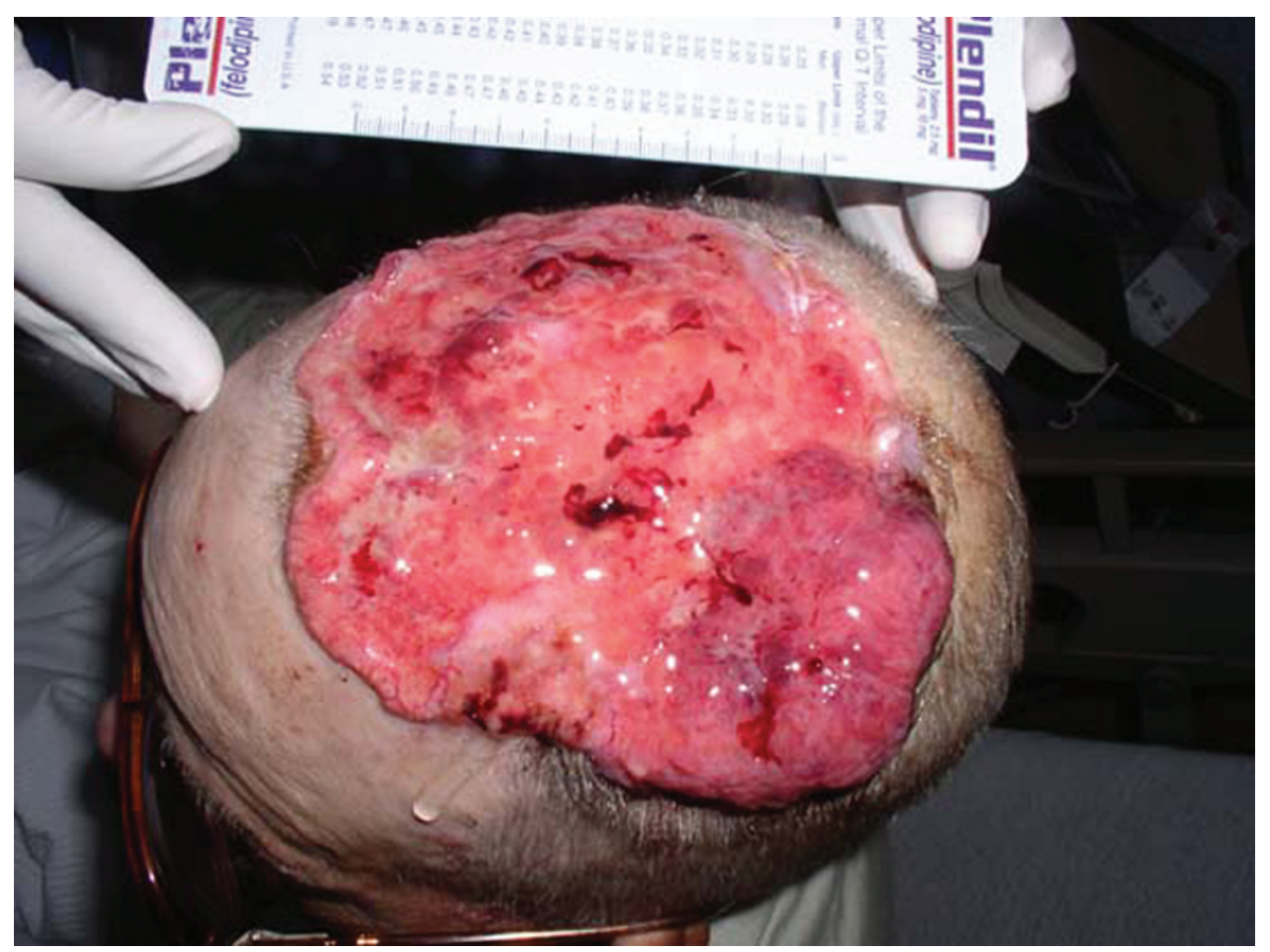

Figure 2 Locally invasive BCC lesion demonstrating active serous drainage.

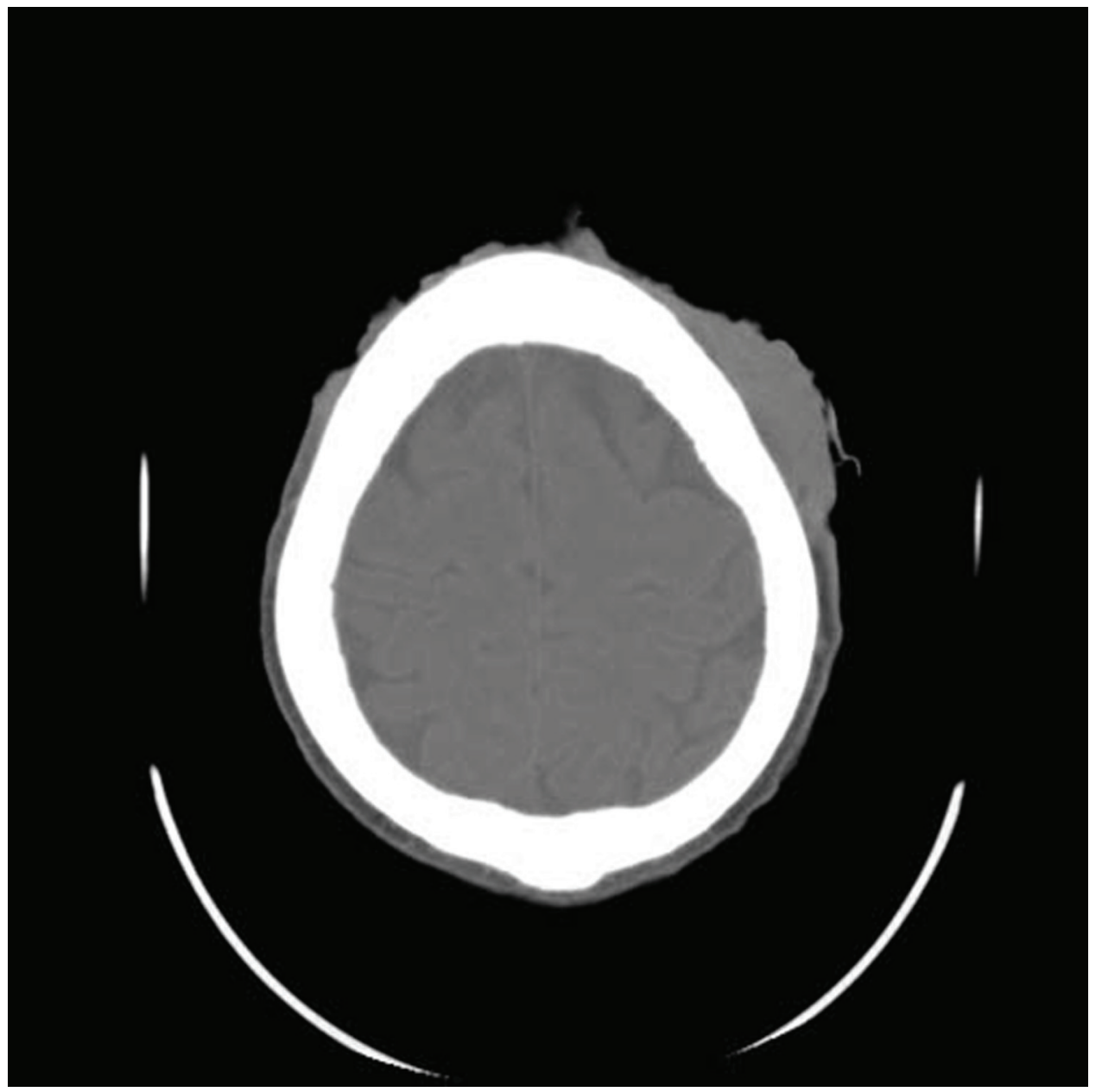

Figure 3 CT head without contrast depicting local soft tissue invasion without bone or brain involvement. 
cells and consult was placed to cutaneous surgery. The patient underwent surgical intervention, which included a wide local excision of the tumour with split thickness skin grafts needed for closure of the lesion. Pathologic analysis of several portions of the lesion revealed an extensively ulcerated basal cell carcinoma (BCC) with vascular invasion identified. The peripheral surgical margins were free of disease, however, several specimens indicated disease in the deep margin of tissue with multiple foci of involvement within the underlying bone itself. Despite his clinical presentation and the surgical findings consistent with local invasion, he was not found to have metastatic disease on imaging studies of the brain and total body (figure 3). The patient's anaemia resolved several months following surgical excision and subsequent colonoscopy was completely normal.

As far as we know, only three other cases of symptomatic anaemia associated with lesions from BCC have been reported in the literature. ${ }^{1-3}$ Interestingly enough, other causes of anaemia associated with extensive BCC include skeletal metastasis and myelophthisic anaemia. There have been a handful of case reports describing a similar presentation of symptomatic anaemia in patients with BCC attributed to metastatic disease and myelophthisic anaemia. ${ }^{4}$ However, this article represents the only case of symptomatic iron-deficiency anaemia from BCC in the last three decades. This article not only reports a unique case of profound anaemia related to a weeping BCC, but it also highlights an unusual presentation of a common malignancy.

Although the presentation of this patient's disease is uncommon, BCC is very common indeed. In fact, more than 1.2 million people are treated for BCC annually. ${ }^{6}$ The patient described in this case has several epidemiological factors that most likely contributed to his disease course.
BCC, which has five main subtypes, has a predilection for males over the age of 40, particularly in those with a history of heavy sun exposure and a poor ability to tan (skin phototypes I and II). ${ }^{7}$ As most would agree, ultraviolet light exposure is a fervent risk factor for any type of BCC. Moreover, states lying closer to the equator, such as Florida, California and Hawaii have an incidence of BCC at least twice that of the Midwestern USA. ${ }^{8}$ It is not surprising that over $90 \%$ of BCCs occur on the face or head. ${ }^{7}$ In addition, superficial therapeutic radiation, as for acne, psoriasis or in this patient's case, fungal infection, increases the risk of non-melanoma skin cancers, including BCC. ${ }^{9}$

\section{Competing interests None.}

Patient consent Obtained.

\section{REFERENCES}

1. Clements WD, Ritchie AJ, Kinley JG. Basal cell carcinoma presenting with profound anaemia. Ulster Med J 1991:60:243-5.

2. Higgins J, Hull SM. Profound anaemia secondary to an ulcerated basal cell carcinoma. Clin Exp Dermatol 1996;21:389-90.

3. Degreef $\mathbf{H}$, Ghekiere L. Extreme iron-deficiency anaemia and basal-cell carcinoma as complications of a circular ulcer of the leg. Arch Belg Dermatol 1974;30:39-42.

4. Kleinberg C, Penetrante RB, Milgrom H, et al. Metastatic basal cell carcinoma of the skin. Metastasis to the skeletal system producing myelophthisic anemia. J Am Acad Dermatol 1982;7:655-9.

5. Schwartz RA, De Jager RL, Janniger CK, et al. Giant basal cell carcinoma with metastases and myelophthisic anemia. J Surg Oncol 1986;33:223-6.

6. American Cancer Society. Cancer Facts and Figures 2000, 2001. http://www. cancer.org (accessed March 2011).

7. Fitzpatrick TB, Johnson RA, Wolff K. 2005. Color Atlas \& Synopsis of Clinical Dermatology. Fifth edition. New York, NY: McGraw-Hill 282-9.

8. Reizner GT, Chuang TY, Elpern DJ, et al. Basal cell carcinoma in Kauai, Hawaii: the highest documented incidence in the United States. J Am Acad Dermatol 1993:29:184-9.

9. Lichter MD, Karagas MR, Mott LA, et al. Therapeutic ionizing radiation and the incidence of basal cell carcinoma and squamous cell carcinoma. The New Hampshire Skin Cancer Study Group. Arch Dermatol 2000;136:1007-11.

This pdf has been created automatically from the final edited text and images.

Copyright 2011 BMJ Publishing Group. All rights reserved. For permission to reuse any of this content visit

http://group.bmj.com/group/rights-licensing/permissions.

BMJ Case Report Fellows may re-use this article for personal use and teaching without any further permission.

Please cite this article as follows (you will need to access the article online to obtain the date of publication).

Breglia MD, Oliva P. Basal cell carcinoma presenting as symptomatic iron deficiency anaemia. BMJ Case Reports 2011;10.1136/bcr.01.2011.3772, date of publication

Become a Fellow of BMJ Case Reports today and you can:

- Submit as many cases as you like

- Enjoy fast sympathetic peer review and rapid publication of accepted articles

- Access all the published articles

- Re-use any of the published material for personal use and teaching without further permission

For information on Institutional Fellowships contact consortiasales@bmjgroup.com

Visit casereports.bmj.com for more articles like this and to become a Fellow 